\title{
Living in the City
}

The Identity Strategies of Schoolchildren in an Urban Setting Confronted by the Stigma of Being "Children of Nongmingong"

\section{Mingchao Zhou}

Translator. Peter Brown

\section{Q OpenEdition Journals}

Electronic version

URL: http://journals.openedition.org/chinaperspectives/7132

ISSN: 1996-4617

Publisher

Centre d'étude français sur la Chine contemporaine

\section{Printed version}

Date of publication: 1 December 2016

Number of pages: 69-77

ISSN: 2070-3449

\section{Electronic reference}

Mingchao Zhou, "Living in the City », China Perspectives [Online], 2016/4 | 2016, Online since 01 December 2017, connection on 28 October 2019. URL : http://journals.openedition.org/ chinaperspectives/7132 


\title{
Living in the City
}

\section{The Identity Strategies of Schoolchildren in an Urban Setting Confronted by the Stigma of Being "Children of Nongmingong"}

\author{
ZHOU MINGCHAO
}

\begin{abstract}
Based on an ethnographic survey in a primary school for the children of rural migrant workers in Hangzhou, this study examines the effects of the process of stigmatisation and the forms of internalisation associated with the "nongmingong" status of their parents. It also looks at how some of these "children of nongmingong" who go to school in the city are able to reverse this stigma. In particular, the study analyses the identity strategies deployed by students aged between ten and fourteen to deal with the stigma of their place of abode, by drawing a distinction between individual strategies (when they are alone with the investigator) and group strategies (in the presence of their peers at school).
\end{abstract}

KEYWORDS: stigmatisation, socialisation, urban segregation, children of rural migrant workers, Hangzhou.

The scholarly legitimisation of the "question of the education of children of rural migrant workers living in an urban setting" in China and the prospects for "integration"

T he household registration system in China known as hukou, ${ }^{(1)}$ originally set up in the 1950s to control migratory flows from rural areas to the cities, is still used today for regulating the urban settlement of such migrants. Those with a rural hukou who have moved to the city do not enjoy the same social and political rights as city people in terms of housing, medical insurance, retrenchment benefits, and education for their children. This makes these "internal immigrants" (2) "marginalised" (3) and an "urban underclass." (4) Hence they remain peasants in terms of their hukou status, even though they might have lived and worked in the city for several decades. These "nongmingong" (rural migrant workers), as they are called in public policy documents, the media, and everyday language, ${ }^{(5)}$ are not only a cheap pool of labour, but also an image of the Other in urban society and a quite distinct element in the representation of the Chinese people, one that is "different from 'peasants' and 'urbanites'" alike. (6) Indeed, they bear an identity that is commonly assumed to be passed on to the second and third generations. Their children, having migrated to the city, are the subject of a specific education policy, categorisation, and segmentation in specially designed city schools that they are required to attend. (7)

The political measures dealing with the education of children from a rural migrant background have thus given rise to the emergence of a new institutionalised category - "children of nongmingong" - in the terminology on education and migration found in policy papers in China. This new category has also sparked the interest of Chinese academic circles that are trying to account for the phenomenon. If media exposure of the problem of educating the children of nongmingong in the cities brought the issue to light in the 1990s without being able to gauge its scope nationally or attract the attention of the political authorities, the year 2001 marked a turning-point in research on the subject. One sign of this was the proliferation of quantitative sociological studies aimed especially at accounting for the situation of private schools set up to receive this group of children in the city. ${ }^{(8)}$
This schooling of children of nongmingong has become a subject of multidisciplinary study today. Some Chinese researchers in sociology and education approach it through the notion of "integration" (rongru 融入) in order to analyse how these students relate to urban society. This research perspective is tinged, however, with a normative outlook, and in my view, the analyses constitute value judgements couched as objective statements. ${ }^{(9)}$ They also tend to shift the question of education in the sense of "schooling" (jiuxue 就学) to one of education in the sense of "upbringing" (jiaoyu 教育)

1. For the hukou system and how it has evolved, see Chloé Froissart, "Le système du hukou : pilier de la croissance chinoise et du maintien du PCC au pouvoir" (The hukou system: A pillar for Chinese growth and maintaining the CCP in power), Les Études du CERI, No. 149, September 2008, pp. 1-47.

2. Jean-Philippe Béja, "Les travailleurs itinérants, des immigrés de l'intérieur" (Migrant workers: Internal immigrants), Perspectives chinoises, No. 21, 1994, pp. 30-35.

3. Liu Kaiming, Bianyuan ren (Marginalised man), Beijing, Xinhua chubanshe, 2003, p. 202.

4. Dorothy J. Solinger, "The Creation of a New Underclass in China and its Implications," Environment and Urbanization, Vol. 18, No. 1, 2006, pp. 177-193.

5. Both in the media and in everyday language one also finds the term dagong mei. This literally means "young (unmarried) sister who sells her labour," used to designate the figure of the female rural migrant worker. Several works have appeared on the subject of female migration in China, particularly in English, for example: Pun Ngai, Made in China: Women Factory Workers in a Global Workplace, Durham, Duke University Press, 2005 (translated into Chinese and published in 2007, and in French in 2012); Zhang Nana, "Performing Identities: Women in Rural-urban Migration in Contemporary China," Geoforum, Vol. 54, 2014, pp. 17-27; Charlotte Goodburn, "Migrant Girls in Shenzhen: Gender, Education and the Urbanisation of Aspiration," China Quarterly, Vol. 222, 2015, pp. 320-338.

6. Chen Yingfang, "Nongmingong: zhidu anpai yu shenfen rentong" (Rural migrant workers: An institutional creation and a social identity," Shehuixue yanjiu, No. 3, 2005, pp. 119-132.

7. Lan Pei-chia has used the term "segmented incorporation" to characterise the urban context in which the systematic exclusion of these "second generation migrants" has now given place to subtler forms of institutional segmentation that continue to reproduce cultural prejudices. See Lan Pei-chia, "Segmented Incorporation: The Second Generation of Rural Migrants in Shanghai," The China Quarterly, Vol. 217, 2014, pp. 243-265.

8. See, for instance, Han Jialing, "Beijing shi liudong ertong yiwu jiaoyu zhuangkuang diaocha baogao" (Enquiry into the status quo of the compulsory education of migrants' children in Beijing"), Qingnian yanjiu, No. 8, 2001, pp. 1-7, and the follow-up study in Qingnian yanjiu, No. 9, 2001, pp. 10-18.

9. Some of them conduct fieldwork in public schools in the city and analyse the "integration" of the migrant children who attend these institutions. For example, Jiang Hua, Xu Xuying, and Chen Qiang talk about the "cultural adaptation" of the children of migrant workers that they define on three levels. The superficial level concerns appearance, including dress style, hygiene, language, and eating habits. The middle level relates to behaviour at school. The deepest level concerns an understanding of classes and codes and the internalisation of values. Jiang Hua, Xu Xuying, Chen Qiang, "Liudong ertong dui chengshi wenhua de shiying yanjiu, yi Beijing shi liangsuo xiaoxue de gean weili" (Studies on the cultural adaptation of migrant children: The case of two primary schools in Beijing), Jiaoyu kexue yanjiu, No. 11, 2007, pp. 29-33. 
within the family and thereby open up the possibility of imputing the problem to migrant workers and their children by explaining the flaws in the system not by the public policies put in place but by the deficiencies of the migrant families and the supposed cultural differences between the latter and city people. These researchers often begin with an observation about the learning difficulties of children and try to locate their causes in their family upbringing. The analyses are formulated in terms of a deficiency, and the whole milieu of the migrant workers is put under the spotlight and judgement is passed: "low Quality" (10) (suzhi di 素质低), (11) a backward conception of education said to be "freewheeling" (fangyang 放养) or "closed," (12) an attitude that values boys and looks down on girls (zhongnan qingnü 重男轻女), (13) etc. Other research, undertaken by actors directly involved in the education sector, namely teachers, tries to propose remedies to shortcomings in family upbringing. Their reasoning is that insofar as children are likely to be influenced by their family upbringing and that their mental health is at risk, all teachers, whatever their subject, must take action to remedy the situation. ${ }^{(14)}$ It is worth pointing out that this line of reasoning is also to be found among teachers in schools that receive pupils from the marginalised working classes in Western societies, one notable example being the ZEP (priority education areas) in France. ${ }^{(15)}$ In reading these articles, one is reminded of the writings of popular proponents of childcare analysed by Luc Boltanski in Prime éducation et morale de classe - which present the working classes as having a certain number of characteristics that turn into their opposite once they have finished their studies. ${ }^{(16)}$ Education conceived in this way is thus imbued with a "civilising mission" that consists of "domesticating" the "little savages," regulating their private life, and replacing their acquired habits with mandatory new ways of behaving aimed at having them accept the values of the upper classes as an ideologically integrated part of the whole social system.

This prospect of "integration" is indicative of a depressing outlook that sees the problem of schooling the children of nongmingong only in terms of deficiencies (a lack of culture in the world of the nongmingong, a psychological vulnerability among children with this background, etc.) and parental failure (lack of availability and ignorance of the importance of education, etc.). In my view, this forms part of a politico-ideological justification for the schooling, insofar as it contributes to the representation of the children of nongmingong and migrant families in terms of a lack, with these "children of nongmingong" being seen merely as victims of their "pernicious background."

In reading the existing literature by Chinese academics I became aware of the paucity of research that actually takes into account the perspective of the users who are directly targeted by the segregationist educational policy, namely these children of nongmingong who are going to school in the city. There is, furthermore, a representation of these children as being passive in their own socialisation process, victims of their family and the social setting of the nongmingong. But socialisation is far from being a matter of cloning; rather, it is "the result of a transaction between the individual and society." (17) It is not one-dimensional and is in no way simply a process of making the actors conform to their environment. Many works concerning pupils in segregated parts of the population in France, for example, have made it very clear that children are active participants in their own socialisation. ${ }^{(18)}$

The present study thus sets out to have the children themselves as the main research focus and attempts to examine the effects of the institutionalised categorisation of them as "children of nongmingong" on the construction of their social identity. This approach is therefore different from the sociology with miserabilist interpretative frameworks ${ }^{(19)}$ of the institutional category of "children of nongmingong."

\section{Stigmatisation as a conceptual tool for analysing interactions with the "children of nongmingong" and the stigma linked to their place of abode}

Erving Goffman defines a stigma as "the situation of the individual who is disqualified from full social acceptance," (20) which can appear as a fixed attribute of a category of individuals or even a kind of atemporal and decontextualised social exclusion. Stigmatisation is then part of the relational social process of devaluing that discredits an individual in the eyes of others in their interactions. The theoretical framework of the stigma, as developed by Goffman, seems relevant for apprehending and analysing the construction of social identity by the "children of nongmingong," insofar as it firstly involves the way in which the stigmatised individuals go about managing their stigma and emphasises the perception and reaction of the actors concerned. The interactive approach that it involves also allows us to better grasp the concrete implementation of the institutionalised and stigmatising category of "children of nongmingong" and its effects on those children. (21) The theo-

10. I translate the term "suzhi" as "Quality" with a capital "Q," following the analysis by Andrew Kipnis, who stresses the overall nature of the suzhi discourse and the slippage between the specificity of a singular quality and "the overall Quality" in the way this discourse is used. Andrew Kipnis, "Suzhi: A Keyword Approach," The China Quarterly, Vol. 186, 2006, pp. 295-313.

11. Xu Hui and Cai Pei, after setting out the problems that they observe in children, such as below average school results, lack of extra-curricular activities, and "low Quality," emphasise the responsibility of the parents. According to these authors, the economic circumstances of these families do not allow the children to have their own study space. The inferior social status of the parents compromises their authority to deal with their children. The lack of social capital among the parents is supposedly passed on to the children, who are also deemed likely to have an inferiority complex. See Xu Hui, Cai Pei, "Chengshi nongmingong chuzhongsheng zinü jiating jiaoyu zhuangkuang chutan" (A preliminary study of the family upbringing of junior high school students who are the children of the nongmingong living in the city), Zhongguo kejiao chuangxin daokan, No. 11, 2010, pp. 162-163.

12. MiWei, "Nongmingong liudong zinü de jiating jiaoyu wenti yu shehui gongzuo de jieru, dui Chengdu shijiao nongmingong jiating diaocha de sikao" (Family upbringing of the children of rural migrant workers and social intervention: some considerations arising from a study carried out within the families of rural migrant workers in suburban Chengdu), Fazhi yu shehui, No. 25, 2008, pp. 282-283.

13. Chen Yao, "Jincheng nongmingong guanyu jiaoyu zinü jiazhiguan zhi bianqian" (The changing views of rural migrant workers on the education of their children), Dajia, No. 4, 2010, pp. 205206.

14. See, for example, Cao Hongli, Wang Yingfang, "Nongmingong zinü yuwen xuexi cunzai de wenti ji chengyin" (The root causes of problems in learning Chinese among children of rural migrant workers), Yuwen xuekan, No. 3, 2011, p. 162-163; Ren Haitao, "Banzhuren ruhe jiaoyu jincheng wugong renyuan zinü" (How should the principal teachers educate the children of migrant workers), Xin kecheng, No. 6, 2010, pp. 40.

15. The acronym "ZEP" stands for zones d'éducation prioritaire (Priority education zones). See Agnès Van Zanten, L'école de la périphérie. Scolarité et ségrégation en banlieue (Schools on the outskirts: Education and segregation in the suburbs), Paris, PUF, 2001, pp. 230-240.

16. Luc Boltanski, Prime éducation et morale de classe (The education bonus and class morality), Paris/The Hague, Mouton, 1969.

17. Annick Percheron, La socialisation politique (Political socialisation), Paris, A. Colin, 1993, p. 8.

18. See, for example, Jean-Paul Payet, François Sicot, "Expérience collégienne et origine ethnique: la civilité et la justice scolaire du point de vue des élèves étrangers ou issus de l'immigration" (High school experience and ethnic origin: Civility and school justice from the point of view of foreign or immigrant students), Migrant-Formation, No. 109, 1997, pp. 155-168; Agnès Van Zanten, L'école de la périphérie. Scolarité et ségrégation en banlieue (Schools on the outskirts: Education and segregation in the suburbs), op. cit.

19. Claude Grignon, Jean-Claude Passeron, Le savant et le populaire: Misérabilisme et populisme en sociologie et en littérature (The Scholar and the Popular: Miserabilism and Populism in Sociology and Literature), Paris, Hautes Études/Gallimard/Seuil, 1989.

20. Erving Goffman, Stigmate. Stigma. Notes on the Management of Spoiled Identity, Prentice-Hall, Englewood Cliffs, New Jersey, 1963. Penguin 1978, p. 9.

21. This is why the notion of discrimination, which refers to objectified social status in the field of law, is not invoked. 
retical framework of stigmatisation enables an investigation of the appropriation of the stigmatising categorisation of "children of nongmingong" by the target students themselves, by stressing their room for manoeuvre in constructing a coherent social identity. By "room for manoeuvre," I mean the fact that they not only come to internalise the categorisation, but also to resist and negotiate it, or even use it in relation to their strategies.

The place of abode of these "children of nongmingong" who go to school in the city is an area that crystallises the importance of the stigmatisation to which these children are subject. The rapid expansion of the cities results in some villages being incorporated into the cities, but at the same time, by virtue of the differences between the city and the countryside, particularly at the level of the regime of land ownership and the hukou, these villages are far from being urbanised and constitute in fact a "floating space" within the cities, with "an urban body and a rural heart." (22) These former villages attract the masses with their affordable rents and practical location in the city, particularly for rural migrant workers looking for cheap housing. These migrants have gradually come together to live in a community and have formed quite a number of groups based around regional or professional affinities. ${ }^{(23)}$ Another element of this is the legal status of these rural migrant workers and the particular and discriminatory treatment they receive. Apartment blocks and those they house have given birth to a negative image of these independent micro-societies of urban society, called chengzhongcun 城中村, literally "villages in the city," which are "synonymous with 'dirtiness,' 'disorder,' 'unhealthy environment,' 'scar' on the metropolis, and a 'breeding ground' for crime." (24) The "children of nongmingong" who live in these chengzhongcun must then take on the image that is associated with them. For those who live in the urban residential neighbourhoods (xiaoqu 小区) ${ }^{(25)}$ surrounded by city people, their stigma is invisible and they may find themselves in a disqualified position with respect to their urban neighbourhood. Their problem will then be how to control information about their stigma.

This raises the question of how the "children of nongmingong" relate to their place of abode and to the urban population (in the sense of hukou) in the city. This study consists of highlighting the identity strategies deployed by children confronted with the stigma attached to the area in which they live. On the one hand, there are individual strategies used to distinguish between those who live in the chengzhongcun and who are subject to the spatial stigma on account of the negative image of their neighbourhood (which is also due to the representation of migrant workers, the main residents in this type of community) and those who live in the urban residential neighbourhoods, surrounded by city people. On the other hand, there are the collective strategies adopted by the children, notably when they are among their peers at school.

\section{Fieldwork and methodology}

This study seeks to shed light on the ways in which students targeted by education policies concerning the "children of nongmingong" in the city appropriate for themselves, negotiate, or resist this stigmatising categorisation in terms of their place of abode. Accordingly, I adopt a micro-sociological approach whereby I place myself at the local level and focus on the concrete interactions of those involved.

During the course of 2010-2012, I conducted ethnographic fieldwork in three stages, covering a total period of nine months (the first stage from the end of February to the end of May 2010; the second stage from early
March to early May 2011; the third stage from late February to late May 2012) in a primary school for children of rural migrant workers living in Hangzhou. In situ, I followed the evolution of one class of some 50 students from the fourth grade, i.e., aged about 10-12 years (in 2010) through to the sixth grade when they reached 12-14 years old (in 2012). As I had been given an official status as a trainee teacher, I had the same timetable as that of the school's regular teaching staff, dividing my time between the classroom and the teachers' room. I adopted a fieldwork methodology combining participant observation, informal interviews, as well as focus group interviews in 2012 with the sixth-grade students within the confines of the school. The material collected, particularly the informal interviews that I did outside the classroom, forms the basis of the present study.

Students at this school actually had a very full timetable and were under a sort of permanent surveillance, a school policy carried out by the teachers. The students were often forced to remain seated during breaks in order to complete their assignments from the previous class or to prepare for the following one. As this form of time management did not allow me to talk with the students without attracting the attention of the teachers, I decided on an informal kind of discussion with them when school got out. This enabled me to make the most of the time I spent with them, in particular through accompanying them on their way home, as I had arranged to pay them a visit there. It was interesting to see how the students introduced their place of residence to me and how they reacted along the way to the fact of my visit, at the same time as I was mindful of my own identity and the manner in which I came across to them as adult / teacher trainee / investigator / resident of Hangzhou in the hukou sense, although I was originally from a prefecture-level city $140 \mathrm{~km}$ away.

These interactions with students outside the school grounds have to be understood in the context in which my research was structured around my being at school five days a week when I was able to observe as a participant with the students. The principle of my study - which I negotiated with the (female) head teacher of the class - was that I would fit into the normal school life of the students: regularly attending class, going to the playground with them, participating in extra-curricular activities such as sporting competitions and springtime excursions, paying them home visits, and being there when they did school assignments. My presence at the school enabled me over time to develop relationships with the students in my class, and during the third sequence of the fieldwork I began to conduct group interviews with them. They were by then - or so it seemed to me - generally more accustomed to my presence at school, as they had already become familiar with "Miss Trainee Teacher Zhou" during the first two periods of fieldwork. I was "Miss Teacher Zhou," as the majority of them almost always called me - although it happened that some called me "big sister" (da jiejie 大姐姐) when we were in an extra-curricular setting such as the springtime

22. Li Peilin, "Les 'villages' dans la Chine en mutation: le cas de Yangcheng à Canton" ("Villages" in a China in transition. The case of Yangcheng in Canton), in Laurence Roulleau-Berger, Guo Yuhua, Li Peilin, Liu Shiding (eds), La nouvelle sociologie chinoise (The new Chinese sociology), Paris, CNRS Éditions, 2008, pp. 237-266, p. 239.

23. For a description of these districts, see Li Chunling, "Migrations villes-campagnes et mobilité sociale" (City-countryside migration and social mobility), in Jean-Louis Rocca (ed.), La société chinoise vue par ses sociologues (Chinese society as seen by its sociologists), Paris, Presses de Sciences Po., 2008, p. 64.

24. Wang Lu, "'Chengzhongcun' gaizao de Hangzhou moshi" (Reconstructing the "villages within the city" of Hangzhou), Zhengce liaowang, No. 3, 2010, pp. 43-45, p. 44.

25. I deliberately translate the word xiaoqu as "urban residential neighbourhoods" for two reasons: firstly, to draw a distinction between the chengzhongcun and the rest of the urban space; secondly, because it is a word used by the students themselves. They refer to the xiaoqu as "the residential neighbourhoods of the city people" (chengliren de xiaoqu). 
outing - but without the authority of being a regular teacher and even less that of a head teacher.

The 51 students in the sixth-grade class were divided into seven groups, and I conducted interviews with these groups in one of the school's meetings rooms. Given the heavy workload at the school, I could only do these interviews once classes were finished for the day, after receiving permission from the head teacher, who arranged for me to have the room. I also had to follow her advice in dividing up the interview groups in relation to the division of students into groups for class duties. However, this way of constituting the group was itself random from the point of view of gender, academic level, and sometimes also social position, based as it was on the division of the "educational support" groups. Each group was thus made up of students whose academic performance was classed by the head teacher as "good," "average," or "poor." This heterogeneity enabled me to explore the diversity of the students' views and their relations to city education in general. The head teacher also informed the parents of the students participating in the interview a day in advance, by writing it down in the correspondence notebook: "Your child will be returning home a little late due to an interview." She said that she never received any comments back regarding this. ${ }^{(26)}$ The average length of the group interviews was one-and-a-half hours, roughly the length of two classes, after a full day at school from 8 am to 3:30 pm. I could not exceed this time, as the children's span of attention had reached its limit. I made use of the focus groups with the aim of gaining insight into the attitudes of the participating children, and their comprehension and perception of a given question, something that would not have been possible on the basis of a single observation or individual interviews.

\section{Students living in the chengzhongcun: Three individual strategies}

Among all the 52 families of the students in whose class I was working as a trainee teacher between 2010 and 2012, 17 lived in flats or storerooms (27) in the urban residential neighbourhoods of the city. My study targeted 35 families living in the chengzhongcun. Five of these families occupied places designed for other purposes - a warehouse, a factory, a commercial outlet, or a company office - part of which had been converted into a residential space. I was interested to discover how these students would present where they lived to me on the trip home and what analyses could be drawn from this concerning the way they related to their place of abode in the city.

Initially, I observed that certain students were defensive and that they set about reconstructing a world with the aid of their imagination. One example of this was a female student in my class. My interest in her family was sparked by a conversation that I had with her in a bus a few days before I visited her home. This 11-year-old girl, having tried to explain to me what her house looked like, ended her description with the words "but [...] maybe you won't like my home." In actual fact, the house was situated by the side of a motorway that crosses a huge wasteland in an outlying suburb to the west of Hangzhou, a two-hour bus ride from the school the girl attended. At first sight, her house resembled a warehouse made of concrete waste. It was divided into two rooms, one of which was a storage room for bulky refuse that it could barely contain, and the second room was a $20 \mathrm{~m}^{2}$ space that served as a bedroom and kitchen. During our trip home, the student never stopped telling me about her house, with the twin aim of softening my shock when I first saw it (her descriptions were preventive) and protecting herself from embarrassment once I saw its actual condition. Thus, the fact that her home was a long way from the city centre was presented as being a deliberate decision to live far out and the guarantee of a precious tranquillity in the city ("It's a long way from the city; I like it, because it's peaceful there, not like downtown, where it's too noisy"). The vast wasteland around the house and the village was described as offering a privileged access to nature that she particularly likened to the advantages of her home village (laojia 老家) ("We have a clear view, like in my laojia," "You can breathe better there because you're closer to nature"). Certain drawbacks of the home were acknowledged, only to be reinterpreted immediately as advantages: "But my parents collect rubbish, and you'll see there is a lot in the house, but that way my parents can do some of their work at home." (Xiang, whose parents were scrap metal workers, was aged 11 at the time of my visit in 2010. Originally from Hunan Province, she had been living in Hangzhou for seven years).

The discourse according to which their house was close to nature was widespread among those who lived in the chengzhongcun on the outskirts. A student by the name of He pointed out to me with a movement of her fingers the small river that crossed her village, after an hour-and-a-half bus ride and a half-hour walk through the mud, and told me that she loved this environment close to nature, even if it meant a long trip to and from home. Later, she confessed to being annoyed about this trip that she had to make every day, but "if this house were closer to the city, it would have been demolished" like the former area in which she had lived in Hangzhou (He was 11 years old at the time of my visit to her home in 2010; originally from Jiangxi Province, she had been living in Hangzhou for five years; her father was an unskilled worker in a factory making metal matrices, her mother a cleaning lady). Another student, a girl called Wu, lived in a chengzhongcun that was slated for demolition soon after. Most of the residents had already moved out, leaving the houses derelict. As a result, there were broken windows through which could be seen the empty interior, and badly tended bushes and green areas at the edge of the neighbourhood area. In spite of this environment having become a slum, the student painted her house as a "princess's cabin in the woods." The state of abandon in the area around where she lived was always talked about in euphemistic terms and sublimated by the promotion of an almost bucolic scene where the overgrown weeds were presented in terms of access to nature (Wu, aged 13 at the time of my visit to her home in 2012, had been living in Hangzhou for 12 years, having originally come from Anhui Province; her father was a school bus driver and her mother a shop assistant in a clothing store). Confronted with a residential context that crystallised their marginality, these children mobilised the resources of their imagination so as to reconstruct a tolerable image of their housing.

The stigma could also be neutralised by humour or even ironic detachment. Some children voluntarily described the most sombre aspects of their village to me, with their own stigmatised expressions for referring to the places. For example, one student living in the urban residential neighbourhood called "hehua yuan" told me about his area on our way to his home,

26. Contrary to a certain received view concerning constraints on conducting a sociological study in China on account of the authoritarian regime, in my fieldwork I had a facility of access in my contact with the children that is unimaginable in a Western context, where the stamp of approval of ethics committees is indispensable for working with sensitive subjects such as those involving children. The control was even less in my case, as most of the parents of the children in that school were either withdrawn or accepted without questioning the school and its representatives, because they were, or could be, disqualified in the eyes of these teachers from a middle class urban background due to their identity as nongmingong. The head teacher in fact had complete control in terms of granting me permission to interview her students.

27. These rooms are often in the basement of residential buildings or in a row opposite. 
referring to the dirtiness and "vulgarity" of his neighbourhood, and with some relish mocked this name hehua yuan, literally "the lotus courtyard": "This name is really misleading. I can't see any lotus there. But rubbish bins, ah yes, it's full of them. It's not 'the lotus courtyard,' but 'the yard with ringworm flowers' (lali hua 癞痢花)." This dialectal expression refers to an illness affecting one's hair, and has a pejorative meaning evoking the unattractive and "harmful" aspect of his area (Fan was aged 11 when I visited his home in 2010; originally from Zhejiang Province, he had been living in Hangzhou for eight years; his father was a foreman and his mother a waitress in a hotel). Another student told me jokingly that he was living in an "enclosed village up in the mountains" (shanzhai 山寨). However, this designation did not spring from a childish romantic imagination to mystify the place in which he lived, as this term could lead one to believe in the Chinese context, for example, the enclosed villages occupied by the outlaw heroes in The Water Margin (Shui Hu Zhuan). (28) What sets it apart from the first case ("the princess's cabin in the woods") is that this image was put forward with the intention of ridiculing the environment of his village instead of transforming the drawbacks into tolerable positive points. Indeed, this student had no problem telling me about the most off-putting aspects of his neighbourhood: the great distance from the city centre, the ramshackle and foulsmelling traditional market, the badly brought up children who played shamelessly in the back alleys of the village, the danger of the young vagabond ruffians, etc. (Jie, aged 12 at the time of my visit to his home in 2011, was originally from Zhejiang Province and had been living in Hangzhou for three years; his father was a welder and his mother a cleaning lady).

In a third case, the stigma can be seen shifted "if not towards its double, then at least towards 'the-nearest-other'." (29) When the students felt exposed to the spatial stigma, they would often point to some of their classmates as a substitute form of stigmatisation. Thus some students freely compared themselves to their peers in describing their housing conditions, always to their own advantage. When I made an observation about the great distance between their place of abode and their school, there was always such-and-such a student from their class who lived even further away, or so they said. When they admitted the fact that dirtiness and disorder was common throughout their village, there was always at the same time a "but" that denounced the place of such-and-such a classmate as being in a worse state than theirs. This was the case with student Zheng. He lived in a chengzhongcun in the city centre, not far from school. This was a one-room flat of $10 \mathrm{~m}^{2}$ barely big enough to fit a bunk bed and a folding table. On seeing how tiny and modest the room was when the student opened the door, I must have let an expression of surprise escape me that was noticed by the student, who said: "Small, isn't it? But you know, my parents only have one child, not like some of my classmates. Sheng, for instance, has two sisters at her place; that's more of a nuisance" (Zheng, aged 13 when I visited him in his home in 2011, was originally from Jiangxi Province and had been living in Hangzhou for four years; his parents were seafood sellers in a traditional market). Or again, there was the time I asked the parents of one of my female students: "How did you find your present flat?" After hearing her parents say that they would have preferred a larger flat for her sake, the student interjected: "Our flat is small, but I went to Guo's and Zhou's places, and ours is bigger than theirs" (Miu, aged 11 when I visited her in 2010, was originally from Zhejiang Province and had been living in Hangzhou for six years; her father worked in a printer's shop, and her mother was a teacher in a private kindergarten in the village within the city where they lived). Through this kind of statement, one can see both the affective closeness and distance between these students: closeness, as this is about a relatively deep shared knowledge, of an "Us" that rests not only on elective affinities, but also on comparable living conditions and a shared spatial stigmatisation; distance, as this same stigmatisation to which they were subject led them to detach themselves from this "Us."

While the students who inhabited the chengzhongcun were subject to the stigma connected with their place of residence and developed justification strategies compared to other migrants who were housed there, the students who lived in the "neighbourhood of the city people" did not experience the same situation.

\section{The students living in the urban residential neighbourhoods: Uncivil little savages?}

In contrast to students who lived in villages within the city, those living in the urban residential neighbourhoods did not take on any negative image of the neighbourhood. They were surrounded by people who for the most part were local urban residents in the hukou sense. By virtue of this, their identity strategies were different from those of their peers.

The case of $\mathrm{Hu}$ is relevant in this regard. He was one of the first students whose home I chose to visit, by reason of its geographical proximity, as we were both living in the same urban residential neighbourhood. Well situated, in an area in which there was a concentration of residential quarters, it was first inhabited by civil service functionaries before being sold off and gradually occupied by people from a diverse range of socio-economic milieus, although a majority of them were white collar workers. Hu and his parents had moved into this area about two years before I went to their home in 2010. According to Hu's mother, they decided to move into that $90 \mathrm{~m}^{2}$ flat so that craftsmen connected to her husband's business could occasionally spend the night there if they worked late. Here is an extract of my fieldwork diary describing the day I visited their home:

One day after school I saw Hu in the bus, and that is how we knew that we lived in the same urban residential neighbourhood. I openly expressed my happiness at such a coincidence, but not $\mathrm{Hu}$, who seemed rather distant and did not seem pleased by this news. Over the following days I asked him several times to meet up with me so we could go home together after school, but he did not wait for me and silently slipped away, until the day when I insisted on going to his place on the pretext of conducting an interview with his parents. He did not say a word and remained on his guard in my attempts to engage him in conversation. Once we entered the neighbourhood area all of a sudden he became mischievous. He had no qualms about walking on the grass where it was forbidden to do so; he stopped in front of the public playground equipment and made use of it in a violent and destructive manner, putting his feet up on the seat of the

28. Shi Nai'an, The Water Margin, also known as Outlaws of the Marsh, Beijing, Foreign Languages Press, 1980

29. Louis Gruel, "Conjurer l'exclusion : rhétorique et identité revendiquée dans des habitats socialement disqualifiés" (Tackling exclusion: Rhetoric and subscribed identity in socially disqualified housing), Revue française de sociologie, Vol. 26, No. 3, 1985, pp. 431-453, p. 437. In his analysis of the inhabitants of socially disqualified places of abode in France, Louis Gruel puts forward the view that the deflection to "the-nearest-other" (l'autre-le-plus-proche) can make a positive difference, however slight, when one is in a position of extreme social disqualification. According to him, this strategy, which is both functional and derisory, belies the necessary ambiguity of the links forged between similarly stigmatised individuals. 
swing, leaning with the full weight of his body on a fragile handle, etc., all the while shouting and laughing loudly, until I frowned and asked him to stop. He seemed rather happy to see me get irritated. With a smirk, he ran off towards home. And once inside the building, he started his antics again by pressing his key into the wall. As he went up the stairs, the key etched a fine line in the wall, while he seemed to be completely indifferent to his actions (...) (30)

Hu's gestures seemed to me to be confused at first. It was only retrospectively, after talking with his parents and getting to know him better, that I managed to interpret them. Actually, Hu was in conflict with their neighbours, particularly the ones who lived on the same landing, on account of the noise problem since they had moved in. Hu's father was a woodcutter and his colleagues transformed the living room of their flat into a woodcutting workshop, and the noise that they made upset the neighbours. The female neighbour on the landing came once in order, in the words of Hu's mother, "to enlighten her rustic neighbours who had come from outside on the etiquette of urban neighbourliness," which the student's father and his colleagues took badly. They accused her of being "a typical city lady, lazy and arrogant," who had no understanding of how hard they worked. This reminder of the norms of civility in the neighbourhood did not spare the student himself. Once, the lady saw him throw a banana peel at the foot of a tree in the neighbourhood and scolded him for it, but, as he told me, he had only done so with the intention of "nurturing the tree with the banana peel." The lady then went to see his parents to complain and asked them to "properly bring up this very low Quality child."

Hu subsequently confided in me that after that incident he had the idea of deliberately engaging in so-called uncivil actions in the neighbourhood in order to "release his resentment at the people there." That is how I understood his playing-up and the rest of his "uncivil actions" that he performed in front of me. I was identified from the outset as a city person living in the neighbourhood, who supposedly shared all the bad traits embodied by the female neighbour. These "uncivil actions" were aimed at destabilising me by showing me the complete absence of consideration that he projected onto these "codes of good neighbourly practice in the city," which were so important for city people like his neighbour and me. (Hu, aged 11 at the time of my visit to his home in 2011, was originally from Zhejiang Province and had been living in Hangzhou for seven years; his father was a timber merchant and his mother a housewife who sometimes helped her husband with his business).

Not all the students were involved in such outright conflict with their neighbours. On the contrary, some children seemed to be on very good terms with them and felt very comfortable in the neighbourhood. This was the case, for example, with Chu, whose mother had moved to Hangzhou after a divorce. There she met her current partner, Mr. Zhao, and brought Chu over the following year. Together with Zhao's son they lived under one roof in a very well-located residence in the district of the school where I was doing my fieldwork, a short distance from the shopping centre. The flat was on the ground floor. Half of it, overlooking the street, was converted into an outlet for the sale of air conditioning units that Mr. Zhao installed; it also served as a living room and study for the family after the shop closed in the evening. The other part of the thirty-something square metres was devoted to their living quarters. Chu's mother was happy and proud to be able to live in this neighbourhood, as, according to her, "few people like us are likely to have access to this standard of living," and it was "thanks to my (present) 'husband,' who left the countryside very early in life and who has worked strenuously in the city ever since," that they managed to rent a flat in that decent neighbourhood and also afford a three-story house under construction in her partner's home village for their later years.

Chu's family was the very first family I visited. This was something that I had proposed to the student during the school's spring outing. He immediately approved of my idea and seemed very accommodating, to such an extent that he took me directly to his house at the end of school, without asking his parents in advance. He showed me his admiration for his neighbourhood, based in particular on a kind of relationship of discovery that he had to it. Accordingly, he said that he had discovered lots of things through living in that neighbourhood: the underground car park, a mushroom-shaped area for rubbish bins, the caretaker's place where cars were checked on arrival, as well as the city children with whom he got on well, the video games they played, and the cartoons they watched. I should point out that his mother encouraged this process of "discovery." According to her, many rural migrant workers did not actually have this opportunity to get to know the world of city people, and she told me that she would be very proud if her son succeeded in being treated as a child of the city and being accepted into his group of friends in the area. Indeed, she "admired" (peifu 佩服) her son because he managed to "play in a friendly way with the city children, as if there was no difference between them" whereas she herself had not managed to make friends. In her view, this was because "he does not see the difference; he plays just as well with the city children as he does with those who are not from the city." However, I observed that Chu was not without the notion of "difference," and in that regard he had the same language as his mother. Witness the following extract from an informal interview:

- Chu: "You will see how nice and clean my neighbourhood is. My family has a shop. Some of my schoolmates come over to my place; they all like this area, because their own is not like that."

- Investigator: "How so?"

- Chu: "Because they don't have any money. Their parents don't have any money to rent a flat in an area like mine. We came here from outside; we aren't rich like those from Hangzhou."

- Investigator: "But your parents ..."

- Chu: "My parents are hard-working and earn more than them, and that's why." (31)

Thus, for him, the grid that usually served to interpret the fact that someone lived in such-and-such a type of housing was skewed by the dichotomy between "Hangzhou people" and "those who come from outside" (waidi lai de 外地来的). The fact of living in this neighbourhood of city people was interpreted as a success requiring remarkable abilities worthy of praise. And when people lived in run-down areas it was regarded as something normal that expressed their stigmatised "difference." On the one hand, he welcomed me gladly into his house because he felt proud of this success. His neighbourhood was presentable in his eyes compared to the environment where his classmates lived. He was conscious of this and found in it a sort of superiority over them. On the other hand, he tended to present himself very much as a child of exceptional "people who come from outside." He showed

30. Extract from a fieldwork diary entry of 12 April 2010.

31. Informal interview with Chu on the way home, before my visit to his home, conducted on 7 April 2010. 
me the bus to take to such-and-such a spot so as to demonstrate that he "knows the city well, just like the locals"; he told me that he rubbed shoulders with city children and took part in their games, "not like his classmates"; he was keen to learn the Hangzhou dialect from his Hangzhou mates in the area, all the more in that he "does not speak the dialect of his own region." He did his best to carefully control the impression that he produced so as to present me with the image of a child of "people who come from outside" who was well integrated in the city. (Chu, aged 12 at the time I visited his home in 2010, was originally from Zhejiang Province and had been living in Hangzhou for a year; he was the son of divorced parents, his step-father running an air conditioning shop while his mother was a housewife).

This intense energy he invested in controlling the impression he produced seemed to me exceptional in a number of respects. Other students, such as Wei, tended to protect themselves by reducing as much as possible the interactions in which they could expose a stigma related to their social situation, for instance with city people or the investigator. Wei was a 12-year-old who lived in a neighbourhood of city people where her parents had a grocery shop. We made our way together to her place, and for the whole half hour or so of the journey the atmosphere was very tense, which was a source of embarrassment for me. As usual, I tried to break the ice, but her very occasional replies to my overtures consisted in a simple "yes" or "no," with her head lowered, avoiding all eye contact with me. She ended up moving away from me following the flow of passengers in the crowded bus. Once we got off, we walked in silence all the way to her home. I sat down in the small grocery store to begin the interview with her father, while she headed straight to the end of the room and disappeared behind the shutters. According to Wei's father, they chose to live in that neighbourhood not only to run their grocery store but also with the aim of providing a healthier environment for their children. In fact, this grocery store gave them an opening to the city people of the neighbourhood, allowing the family to communicate with them on the basis of commercial relations.

However, Wei did not seem to be pleased with this environment, according to some of her father's remarks: "She does not take advantage of the opportunity"; "she keeps to herself, she doesn't even help me when I ask her to greet the customers." He began by imputing his daughter's withdrawn attitude to her reserved and timid character, before relating an anecdote. In fact, as the daughter of the person who ran the local grocery store, she was actually very visible in the neighbourhood. Almost all the residents knew her face, not to mention neighbourhood children who came to buy lollies after school. I do not know at what point or under what circumstances certain children in the neighbourhood began to call Wei the "grocery store Miss" (xiaomaipu daxiaojie 小卖铺大小姐). Wei's father considered this trivial teasing among children, but in the eyes of Wei, this name was not without an ironic connotation. Her analysis was as follows:

It's teasing. They make fun of me and my family because we are not from Hangzhou. I'm just a country girl in their eyes, not this so-called "Miss."

It was after some time spent in the class, on my second stint of fieldwork, that I grasped Wei's perspective. She also said that she preferred to keep a low profile so as not to attract the potential attention of city people. In hindsight, this gave me a better understanding of Wei's withdrawn attitude when she was with me on the trip home. Identified as a city person, I had the power to intimidate her. Above all, she did not want me to hear other children from the neighbourhood calling her "Miss," for fear that I might ask her about it. Hence this withdrawn behaviour to protect herself from my questions and even the way I might look at her. (Wei, aged 12 when I visited her home in 2011, was originally from Zhejiang Province and had been living in Hangzhou for 11 years; her parents ran a grocery store).

Individual strategies were developed when children were alone with the investigator asking questions, without their peers. However, when we moved into a group context, their discourse became quite different.

\section{Demarcation strategies in group interviews}

When we moved to a group context, I asked the question "How do you find the environment where you live in Hangzhou?" In response, the children put forward the advantages of their place of abode, in particular through the metaphor of the family, as illustrated by the following extract:

- Fan (a 13-year-old boy, whose father was a foreman and whose mother worked as a waitress in a hotel; the group leader according to the principle of the aforementioned division of groups, he lived in a chengzhongcun in the same district as the school, 30 minutes away; the joker of his neighbourhood during the one-to-one informal interview with the investigator quoted above): "The good thing about my neighbourhood is..."

- Shen (a 13-year-old boy, whose parents were chicken feet merchants, living in the same chengzhongcun as Fan): "I know! Because I live in the same neighbourhood as him (laughter). We know each other well there. I don't mean everyone, but at least the ones who live in buildings nearby. (to Fan) Isn't that right?"

- Fan (the leader of the group, who lived in the chengzhongcun): "Yes, there's also Liu who lives in our part of the neighbourhood; the three of us are always together. We're like brothers and sisters. We often go to school together and take advantage of living near each other to study or play together after school."

- Zhang (a 14-year-old boy, whose parents ran the grocery store; a poor student, living in an urban residential neighbourhood that was a half-hour bus ride from the school) (with a look of envy): (To Fan) "Yes, I see you the whole time together on the way back home. That's cool!"

- Song (a 13-year-old girl, whose parents were taxi drivers, a good student who lived in a chengzhongcun an hour's bus ride from the school): "I've just moved in to my neighbourhood and I like it there, as I'm with my uncles and aunts and nieces again. We live on the ground floor, my great-uncle's family occupies the first floor, and the family of my second uncle is on the second floor. My parents also know the other neighbours well, and some of their children go to my school."

- Fan (the group leader, who lived in the chengzhongcun): "Yes, it's not like those neighbourhoods with city people, where you don't even know who your neighbours are."

- Chai (a 12-year-old girl, with a bus driver father and a mother who was a housewife, an average student, living in a chengzhongcun in the district of the school a 45-minute bus ride away): "Yes, I know the people who live nearby well. I've got a cousin who lives in a neighbourhood full of those city people. It's over towards the Eastern Rail- 
way Station. He told me he was lonely. In fact, once he's back home he's got no one to talk to apart from his parents. I've already been to his place. The neighbourhood is nice and tidy. His flat is big, and he's got his own room and everything! But I prefer my neighbourhood."

- Wang (a 14-year-old girl, whose parents were rice merchants; an average student, she lived in a warehouse in the north-east suburbs of the city, and it took her over two hours by bus and on foot to get to school): "Yeah, I can play hide-and-seek with the children, but when my father treats the rice he makes a lot of noise."

- Chen (a 12-year-old girl, whose mother, a divorcee, worked as a shop assistant in a store selling electronic goods; an average student, she lived with her mother, her grandmother, and her aunt's family in an outlying chengzhongcun, a two-hour bus ride from school): "I live with my mother, my aunt, my uncle, my niece, and my grandmother. My mother only needs to pay part of the rent. She says that when she has earned some more money she'll move with me to a better area, closer to school, and more expensive and better quality, but I prefer to stay in this house, because if there are only the two of us living together I don't know who I can talk to apart from my mother." One member of the group, Ding (a 14-year-old boy, whose parents were vegetable sellers; a poor student, who lived in an urban residential neighbourhood a half-hour bus ride from the school) did not answer this question and merely proffered a smile when I pressed him on it. (32)

Through this extract one can see the contrast between the anonymous coldness of the city people and the warm familiarity of the chengzhongcun residents, even if the students did not put it in those terms. The students spoke freely, each time beginning by confirming the views of the previous speaker. One could hear the binary stereotype based on the clichés of an anti-social individualism prevalent in the "city people's neighbourhoods" and the situation in the chengzhongcun where the residents all know each other. It is possible to say that neighbourly relations are put on the same plane as family relations. This was certainly the view expressed by students Song and Chen, who were actually able to get their family back by moving into their village. Their statements, aimed at showing how deeply connected they felt to their locality, including having neighbours as substitute family members, served to highlight the contrast with the "city people's neighbourhoods," where a cold anonymity was the order.

The attitude expressed by Fan, the neighbourhood joker, during his informal one-to-one interview with the investigator, seems interesting to me. In spite of the various ways he decried his own neighbourhood at the time of my visit to his home, he began to defend it in the group interview setting. These two attitudes are not contradictory, however; it is rather about different strategies for reversing the stigma. This community discourse that traces the border between "We the inhabitants of our neighbourhood" and "They, the city people who live in the city people's neighbourhoods" contributes, in my view, to socialising the local acceptability of each child of the chengzhongcun, islands of connectedness in a vast oceanic expanse of strangers, of the Other.

The group artificially formed by the collective interview gave the students living in the chengzhongcun the opportunity to leap to the defence of their neighbourhood. The situation of the collective interview seemed to favour group alignment and the articulation of a militant community discourse. For some, one can say that the group gave them the strength to break the silence and express their displeasure at the stigmatisation to which they were subjected, as was the case with Xiang, the daughter of scrap merchants whom I mentioned above. In the group interview, she made a categorical remark about the attitude of indifference among city people ("Yeah! The city people are indifferent and cold," echoing the observation of her classmate that "the Hangzhou children stay at home all the time"). After the group interview, I went back by bus with Xiang, who began to share with me her impressions of this last interview. She confided to me her displeasure at the attitude of the head teacher during the visit she paid to her home. According to Xiang, this head teacher annoyed her father by asking him to "rearrange the home to give it a more propitious atmosphere" for his daughter's studies. Xiang herself did not appreciate the attitude of the teacher, for "she looked disgusted, as if the house was dirty." And "you could see that in the way she frowned and cleaned the chair before sitting down." In addition, she said that she felt less embarrassed to answer back to me in the presence of her classmates with the same residential situation than when she had to face her teacher's judgement about her parents, and to which she had not dared say anything. It is impossible to know if the teacher actually did behave as the student described, but in any case, the group interview in the presence of her peers was an opportunity for her to express her pent-up displeasure at the humiliations she had felt.

For the other students, their statements condemning "the neighbourhoods of the city people" bore witness especially to a rhetoric marking their solidarity. After the group interview, Fan, the local joker, when asked about his own mixed views about his neighbourhood, led me to believe that he did not want to annoy the other students by describing the bad sides of their neighbourhood, particularly those who lived in the same village as he did, as in the end "we are all together" (women shi yiqi de 我们是一起的). This "we are together" not only recalls alignment with the stigmatised group, but also the daily presence, both physical and material, of the group within the school.

\section{Conclusion}

The views of the "children of nongmingong" about the differences in habitat considerably widened the gap between "Them, the city people" and "Us, the people from outside." At the same time, within this "Us," there were many lines of demarcation that more or less allowed for self-demarcation from the many "Them," made up of other children of nongmingong whose parents did not enjoy the same level of income, the same social status, the same type of profession (manual work, service sector, business). They put in place at least six types of individual identity strategies. However, when they moved to a collective context, we observed an alignment with the group and a positive appreciation of the chengzhongcun and those who lived there. This study has consequently brought out the fact that the children are actors of their own socialisation, which sets it apart from a depressing sociology of the institutional category of "children of nongmingong" that consists of putting forward alarmist statements about the psychic troubles from which these children supposedly suffer and envisages their education in the city only in terms of shortcomings, parental deficiencies, and problems.

A caricature archetype would have it that the first generation of rural migrants, former agricultural workers, moved to the city where they settled and were cut off from their home village for many years until they returned to see out their days there. Accordingly, for them, an urban lifestyle was

32. Group interview No. 5 conducted on 26 April 2012. 
parallel to a rural lifestyle, rather than in competition with it. By contrast, their children constitute the first generation of native urban dwellers. These young people, although unable to find in their elders a model to emulate at the various stages of their passage through life, show themselves capable of developing new styles based on their experience as children raised in the city. The "education of the children of nongmingong" is indeed a major political issue for the government of the Chinese Communist Party: how to legitimise this educational inequality and maintain political legitimacy when faced with this new generation and their parents, who are the agents of the country's economic development?
I Translated by Peter Brown.

Ihou Mingchao, who completed a doctorate in political science at the University of Aix-Marseille, France, is a postdoctoral researcher at Hangzhou Normal University (Institute for Urban Studies).

Hangzhou Normal University, 58 Haishu Road, Cangqian Campus, Yuhang District, 310036 Hangzhou, Zhejiang Province (charline.zhou@gmail.com).

Manuscript received on 16 April 2015.

Accepted on 12 July 2016. 